\title{
Great Purple Hairstreak; Great Blue Hairstreak Atlides halesus (Cramer) (Insecta: Lepidoptera: Lycaenidae) ${ }^{1}$
}

Donald W. Hall ${ }^{2}$

\section{Introduction}

The great purple hairstreak, Atlides halesus (Cramer), is one of our most beautiful and fascinating southern butterflies (Figures 1 and 2). Although its preferred and most frequently used common name is great purple hairstreak (Miller 1992), it does not have any true purple coloring on it. A few publications (Gerberg and Arnett 1989; Emmel 1975; Pyle 1981) use the name great blue hairstreak, which is more appropriate.

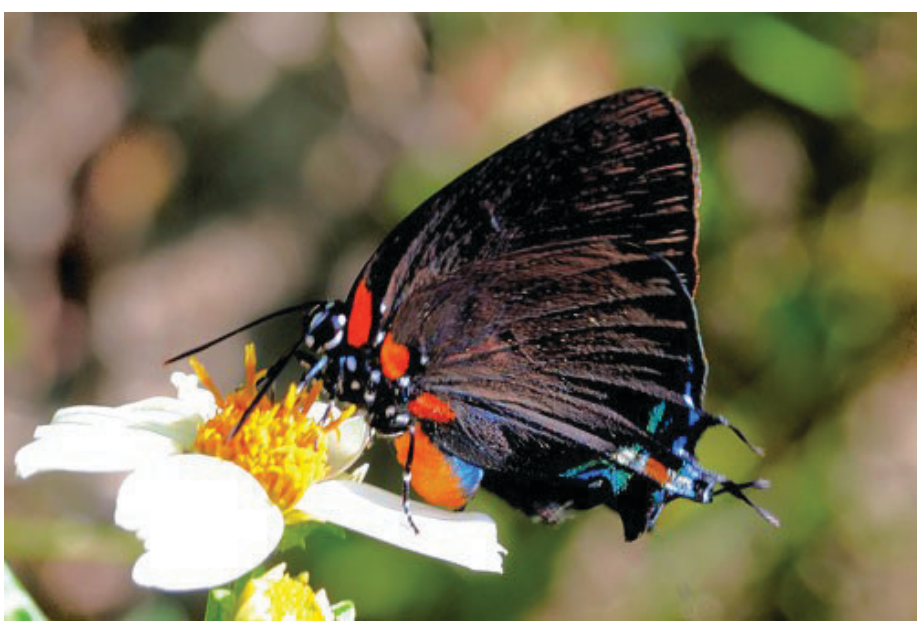

Figure 1. Female great purple hairstreak, Atlides halesus (Cramer) on beggarticks, Bidens alba (L.).

Credits: Donald W. Hall, UF/IFAS

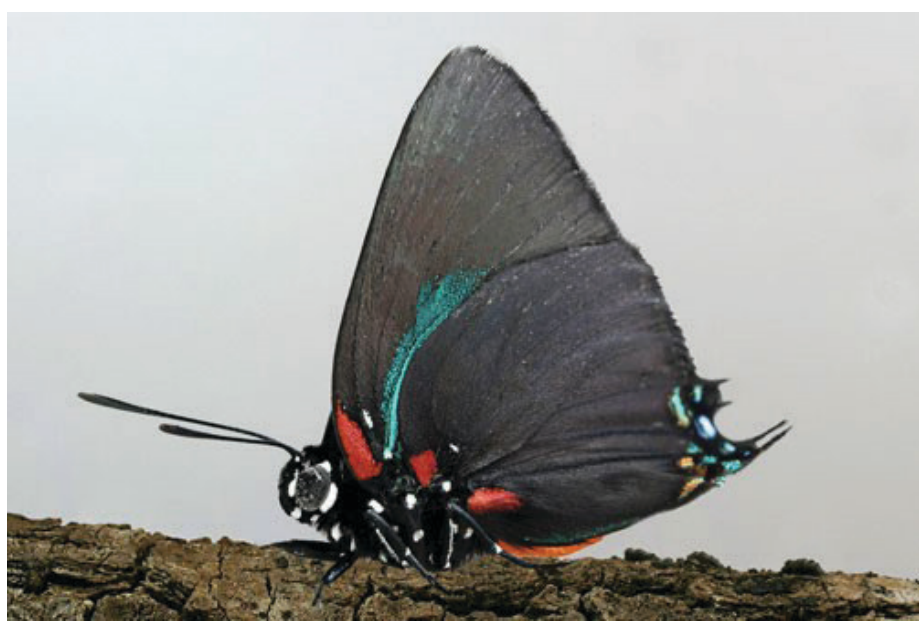

Figure 2. Male great purple hairstreak, Atlides halesus (Cramer). Credits: Donald W. Hall, UF/IFAS

How Atlides halesus came to be known as the great purple hairstreak is a mystery. Pyle (1981) described the female as being purplish-gray below, and Evans (2008) mentioned that the undersides of the wings have a purplish sheen. Cech and Tudor (2005) stated that the female fades to brownish purple with wear.

\section{Nomenclature}

The original genus name for the great purple hairstreak was Papilio. It has also been placed in the genera Hesperia, Polyommatus, and Thecla (Scudder 1876).

1. This document is EENY-110, one of a series of the Entomology and Nematology Department, UF/IFAS Extension. Original publication date August 1993. Revised August 2010, August 2013, August 2016, and September 2020. Visit the EDIS website at https://edis.ifas.ufl.edu for the currently supported version of this publication. This document is also available on the Featured Creatures website at http://entomology.ifas.ufl.edu/ creatures.

2. Donald W. Hall, professor emeritus, Entomology and Nematology Department; UF/IFAS Extension, Gainesville, FL 32611.

The Institute of Food and Agricultural Sciences (IFAS) is an Equal Opportunity Institution authorized to provide research, educational information and other services only to individuals and institutions that function with non-discrimination with respect to race, creed, color, religion, age, disability, sex, sexual orientation, marital status, national origin, political opinions or affiliations. For more information on obtaining other UF/IFAS Extension publications, contact your county's UF/IFAS Extension office. U.S. Department of Agriculture, UF/IFAS Extension Service, University of Florida, IFAS, Florida A \& M University Cooperative Extension Program, and Boards of County Commissioners Cooperating. Nick T. Place, dean for UF/IFAS Extension. 
Scudder (1876) listed the following synonyms:

Atlides dolichos Hübner

\section{Atlides dolichus Hübner}

\section{Thecla juanita Scudder}

Opler and Krizek (1984) suggested the following possible derivation for the current genus name Atlides: "The genus name is possibly an incorrect formation for Atlantides, meaning the 'race of Atlas." They also stated that the specific epithet halesus is named after Stephen Hales, a well-known English botanist.

\section{Distribution}

The great purple hairstreak is found throughout the southern United States where its host plants are found (Figure 3) and southward to southern Mexico. It is found farther north along the eastern coast of the United States to Maryland. The distribution of its caterpillar's mistletoe host plant extends farther north into the southern areas of Ohio, Indiana, Illinois, and Missouri (Plants Database 2019), and it is likely that the butterfly may also be found in some of these areas. It is much less common in the northern part of its distribution (Emmel 1975).

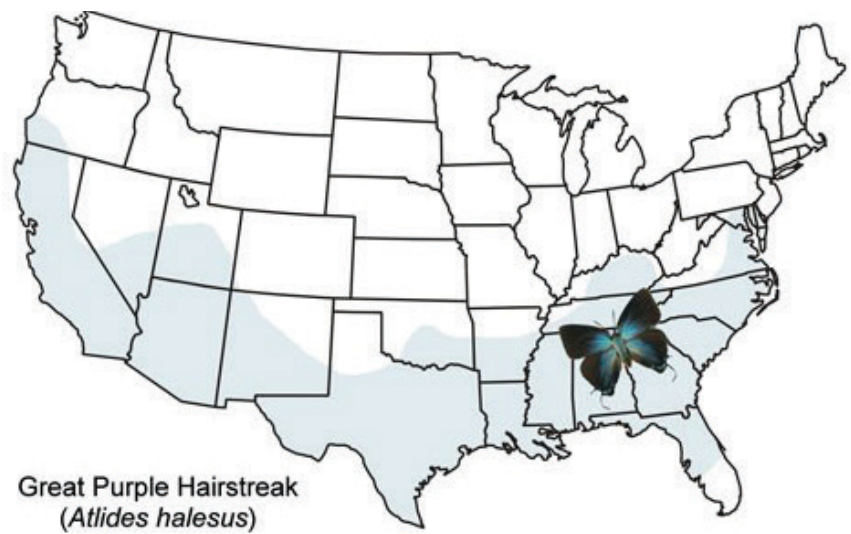

Figure 3. Great purple hairstreak, Atlides halesus (Cramer), distribution map.

\section{Description}

\section{Adults}

The wingspread is 1.25 to 1.5 inches (Allen 1997, Gerberg and Arnett 1989). The upper sides of the wings are iridescent blue with black borders (Figures 4 and 5). Females are duller. The iridescent areas on the wings of males are more extensive than those of females. Each hind wing has two black tails (hairstreaks) of unequal length. As mentioned earlier, the common name great purple hairstreak is not descriptive of the adult butterfly's true coloration.

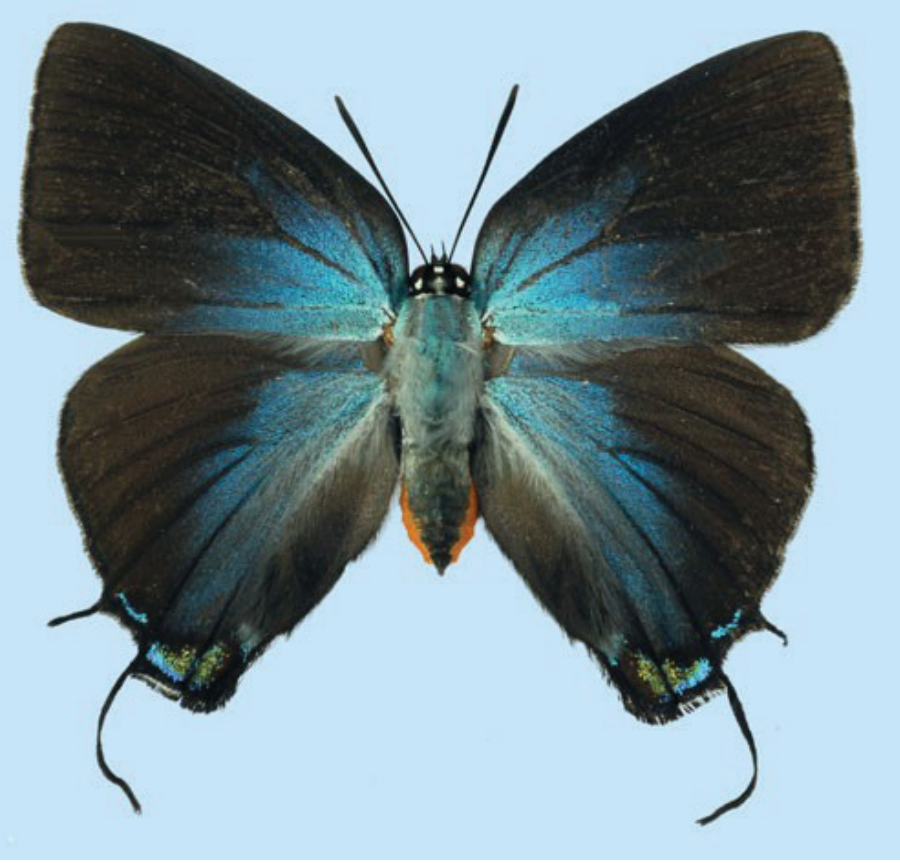

Figure 4. Female great purple hairstreak, Atlides halesus (Cramer), upper surface.

Credits: Lyle J. Buss, UF/IFAS

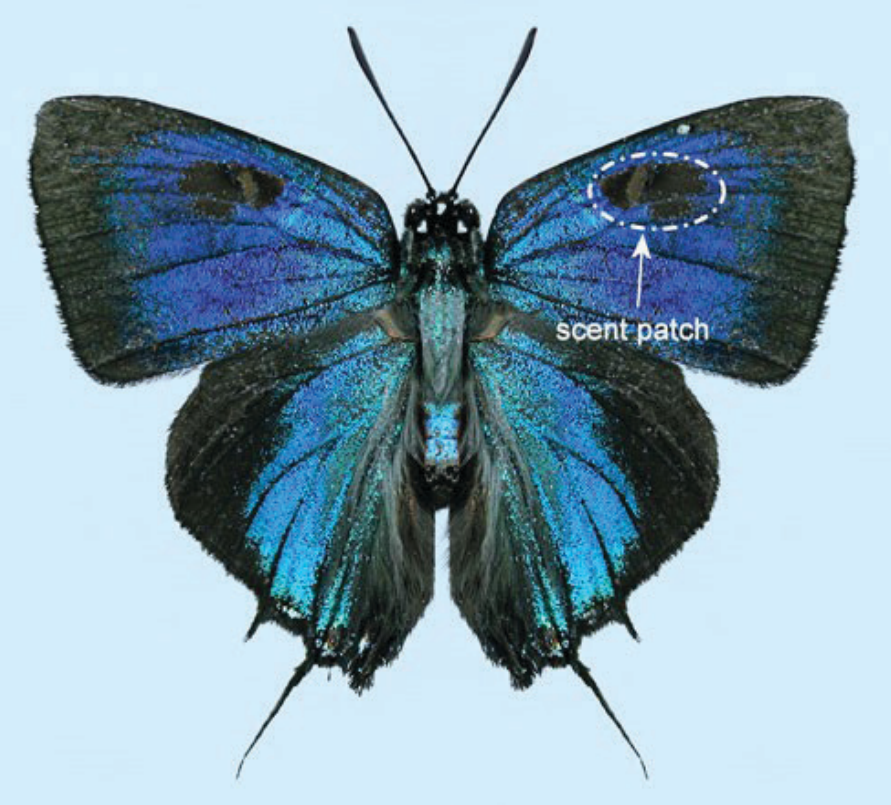

Figure 5. Male great purple hairstreak, Atlides halesus (Cramer), upper surface. Note patch of scent scales.

Credits: Donald W. Hall, UF/IFAS

The underside of the abdomen is orange in both sexes. The undersides of the wings are dark brownish-black with three basal, bright reddish-orange spots (one on the front wings and two on the hind wings) with lines of greenish and blue spots on the margin of the hind wings at the bases of the tails (Figures 1 and 2). Males have an iridescent blue streak on the underside of the front wing (Figure 2) that is sometimes obscured by the leading edge of the hind wings. Males also have a patch of scent scales on the upper side of 
the forewings (Emmel 1975; Martins et al. 2018) (Figure 5) that produce pheromones for courtship (Minno and Minno 1999).

\section{Eggs}

The flattened eggs are white and have a central micropyle (pore through which sperm enter) on top. They are approximately $0.8 \mathrm{~mm}$ (approx. 0.03 inches) in diameter and $0.2 \mathrm{~mm}$ (approx. 0.008 inches) in thickness (Figure 6). The surface is covered with fine sculpturing.

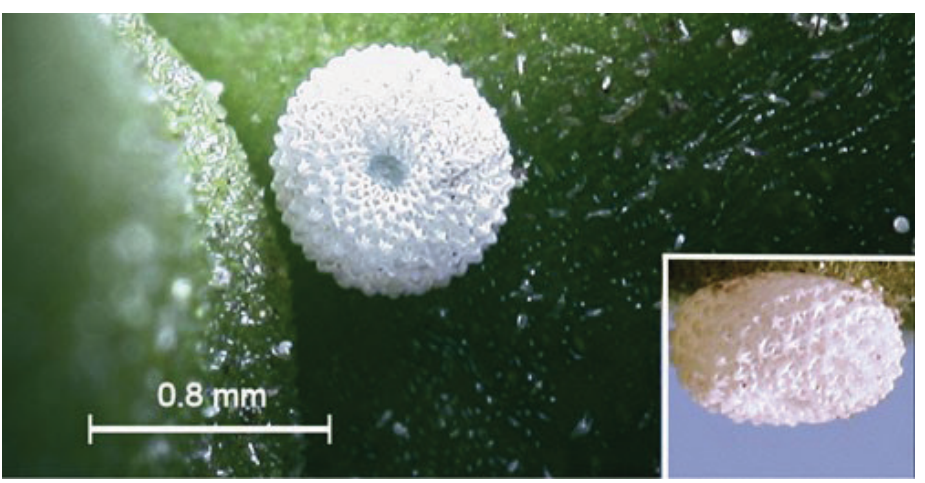

Figure 6. Great purple hairstreak, Atlides halesus (Cramer), egg (inset: side view).

Credits: Donald W. Hall, UF/IFAS

\section{Larvae}

Mature larvae are approximately $2.5 \mathrm{~cm}$ (approx. 1 inch) long, green with a dense covering of short, fine light orange hairs and a small whitish shield on the thorax (Minno et al. 2005) (Figure 7).

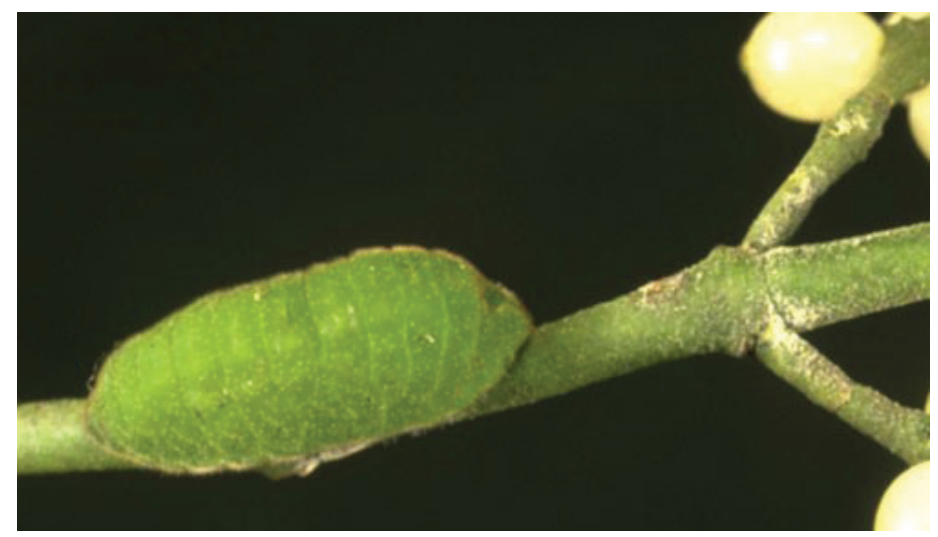

Figure 7. Great purple hairstreak, Atlides halesus (Cramer), larva on mistletoe.

Credits: Jerry F. Butler, UF/IFAS

\section{Pupae}

Pupae are dark brown mottled with black.

\section{Host Plant}

\section{Larval Hosts}

Larvae feed only on plants of the parasitic mistletoe genus Phoradendron (Viscaceae) (formerly placed in family Loranthaceae). Phoradendron species are hemiparasites on trees from which they gain water and inorganic nutrients, but their leaves contain chlorophyll and are capable of photosynthesis (Zomlefer 1994). The genus name Phoradendron is derived from the Greek roots "phora" (to bear or carry) and "dendro" (tree) (Borror 1960, Gledhill 1989) in reference to the fact that they grow on trees. Mistletoes are dioecious (with male and female flowers on different plants).

Oak mistletoe, Phoradendron leucarpum (Raf.) Reveal \& M.C. Johnst. (Figure 8), is the only host for the great purple hairstreak in the southeastern United States. It is found from central Florida west to Texas and north to southern areas of Illinois, Indiana, Ohio, Pennsylvania, and New York (eFloras.org 2017, Plants Database 2019, Spooner 1983).

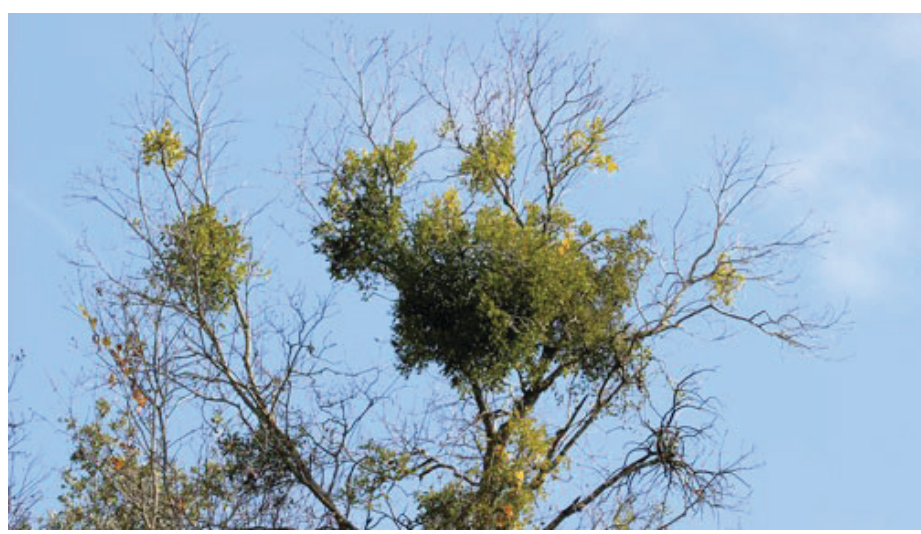

Figure 8. Oak mistletoe, Phoradendron leucarpum (Raf.) Reveal \& M.C. Johnst., in pignut hickory, Carya glabra (Mill.) Sweet. Credits: Donald W. Hall, UF/IFAS

The specific epithet leucarpum is derived from the Greek roots "leuc" (white) and "carp" (fruit) (Borror 1960; Gledhill 1989) in reference to the berries which are white when mature (Figure 9). In the past, oak mistletoe has been commonly known by the synonyms Phoradendron serotinum (Raf.) M.C. Johnst. and Phoradendron flavescens (Pursh) Nutt (eFloras.org 2017; Kuijt 1982; Plants Database 2019; Wunderlin et al. 2019).

Oak mistletoe is pollinated by insects - probably wasps and bees, and possibly ants (Coder 2008; Kuijt 1982). The seeds are sticky and disseminated by birds (Coder 2008; York 1909). In spite of the common name oak mistletoe, Phoradendron leucarpum parasitizes more than 105 tree species belonging to over 50 genera (Coder 2008; Scharpf and Hawksworth 1974), and I have also found it on 
oleander (Nerium oleander L.), a common landscape shrub in the southern United States.

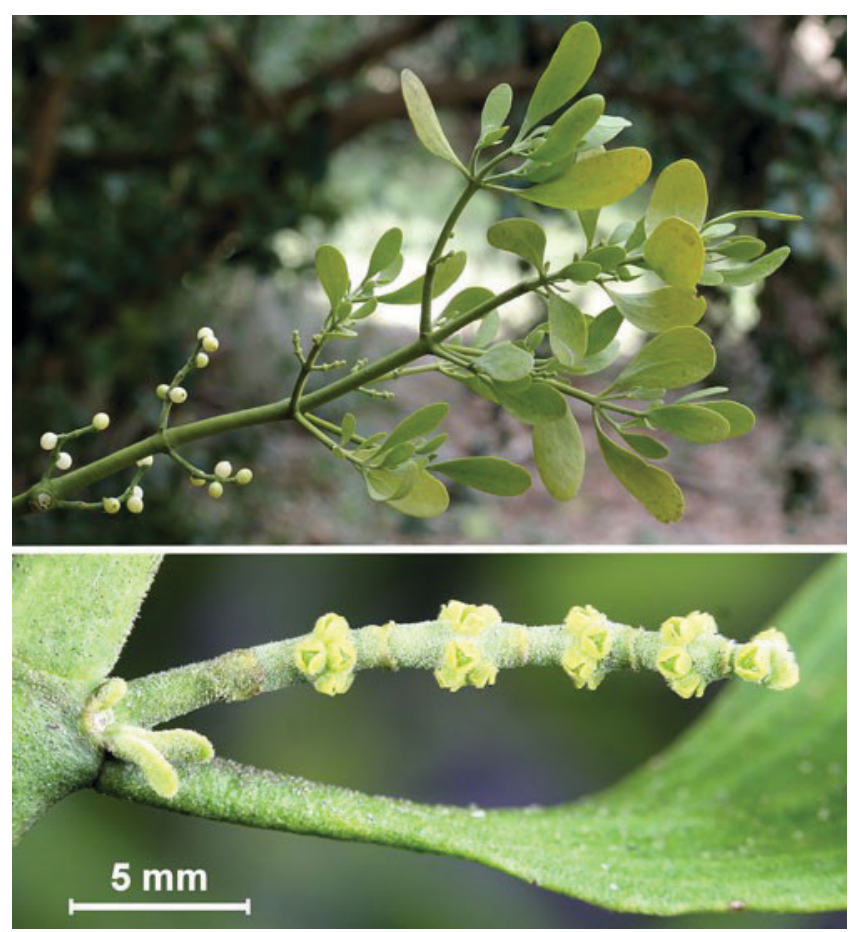

Figure 9. Oak mistletoe, Phoradendron leucarpum (Raf.) Reveal \& M.C. Johnst. Top: pistillate (female) branch with current year inflorescences (= flowering part of plant) and mature berries from previous year's flowers. Bottom: enlarged pistillate inflorescence.

Credits: Donald W. Hall, UF/IFAS

Mistletoes have a reputation of being highly toxic. However, much of this reputation is probably due to ingestion of plant parts or steeped teas of European mistletoe, Viscum album L. (Viscaceae) which contain a toxic protein called viscotoxin. Oak mistletoe also contains a toxic protein (phoratoxin), but it has been shown to be only about onetenth as toxic as viscotoxin (Rosell and Samuelsson 1966; Samuelsson and Ekblad 1967). It is unknown whether great purple hairstreak larvae sequester the phoratoxin.

Most accidental ingestions of oak mistletoe plant parts have produced mild or no symptoms (Evens and Stellpflug 2012; Hall et al. 1986; Krenzelok et al. 1997). In fact, Native Americans used mistletoe as a medicinal treatment for many ailments (Moerman 2009; Hutton 2010).

\section{Adult Nectar Sources}

Great purple hairstreaks will feed on nectar from many kinds of flowers. The following have been mentioned as favored nectar sources (Cech and Tudor 2005; Gerberg and Arnett 1989; Haskin 1933; Minno and Minno 1999; Opler and Krizek 1984):

Wild plum (Prunus spp.)
Beggar ticks (Bidens alba [L.] DC.)

Sweet pepperbush (Clethra alnifolia L.)

Goldenrod (Solidago spp.)

Hercules club (Zanthoxylum clava-herculis L.)

Garberia (Garberia heterophylla [W. Bartram] Merr. \& F. Harper)

Saw palmetto (Serenoa repens [W. Bartram] Small)

For photographs of these nectar plants, see Wunderlin et al. (2019).

\section{Life Cycle}

There are three generations in most of the southeastern states (Opler and Krizek 1984), but adults have been found year-round in Florida (Moth Photographers Group undated, Opler and Krizek 1984). Males perch on treetops during the afternoon to await the arrival of females for mating. Eggs are laid singly or in small groups on foliage of the host plant (Haskin 1933, Minno et al. 2005). Eclosing (hatching) larvae eat their way out of the eggs by chewing a circular hole in the top of the egg (Figure 10). Newly hatched larvae of many butterfly species eat the egg shell as their first meal (Opler and Krizek 1984), but newly hatched great purple hairstreaks do not.

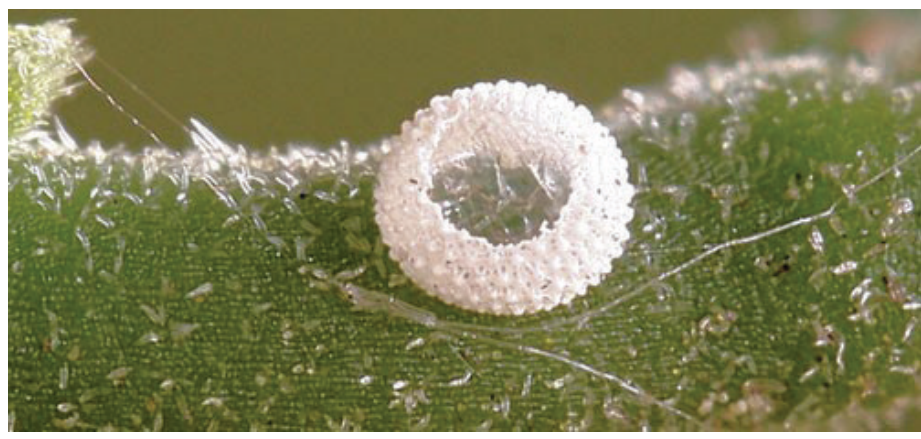

Figure 10. Great purple hairstreak, Atlides halesus (Cramer), egg showing circular hole chewed by hatching larva.

Credits: Donald W. Hall, UF/IFAS

Larvae are reported to feed on young leaves and male (staminate) flowers (Figure 11) (Minno and Minno 1999) and probably also eat female flowers.

When full-grown, larvae migrate from the mistletoe and pupate under loose bark, in crevices of bark or under leaf litter at the base of the tree. 

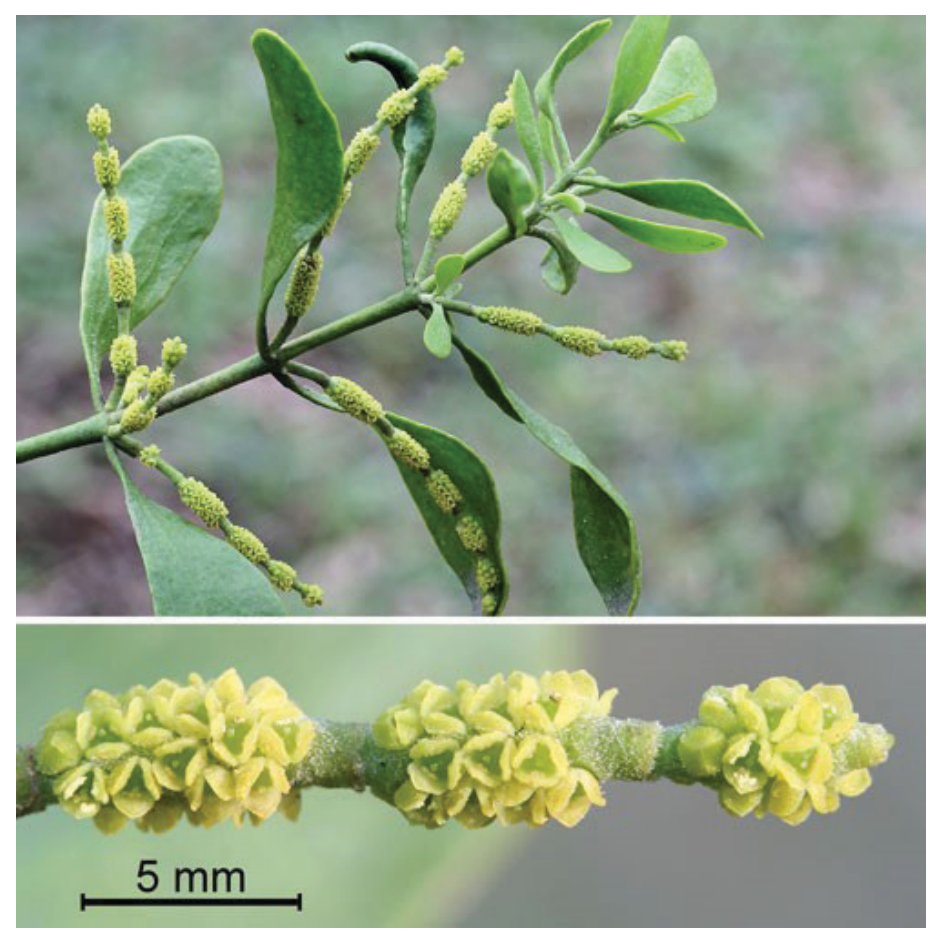

Figure 11. Oak mistletoe, Phoradendron leucarpum (Raf.) Reveal \& M.C. Johnst. Top: staminate (male) branch with inflorescences (flowering part of plant). Bottom: enlarged staminate inflorescence.

Credits: Donald W. Hall, UF/IFAS

\section{Natural Enemies}

Whitaker (1984a, b) reported that an unidentified hymenopteran parasitoid was a major source of egg mortality and that braconid wasp parasitoids (Apanteles sp.) emerged from many third instar larvae and pupated in cocoons spun under the hollow host exoskeletons (Figure 12). The egg parasitoids emerge from eggs by cutting holes in the side of eggs in contrast to the holes cut in the tops of eggs by eclosing caterpillars (Whitaker 1984a).

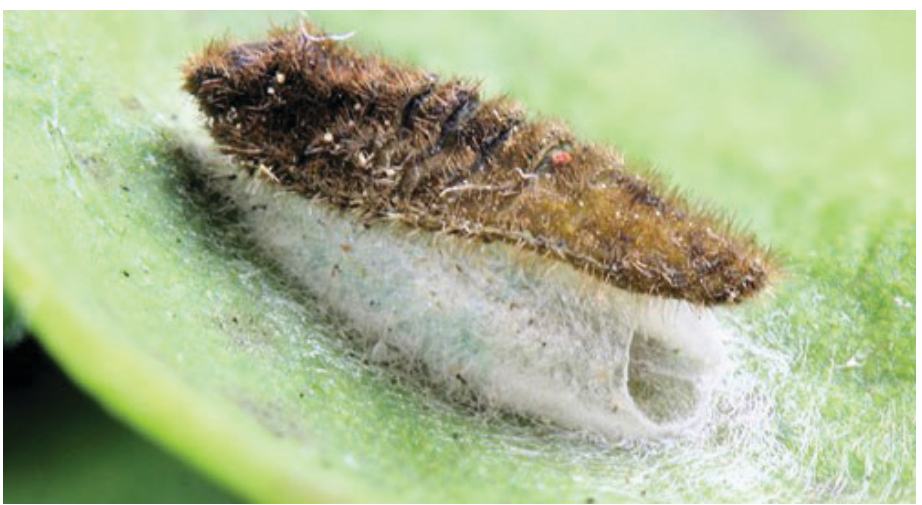

Figure 12. Hollow exoskeleton of third instar great purple hairstreak, Atlides halesus (Cramer), larva on top of cocoon from which a parasitoid wasp (probably Apanteles sp. [Braconidae]) had emerged. Credits: Donald W. Hall, UF/IFAS

Pupae are frequently parasitized by parasitoid wasps (Scott 1986) - probably the chalcidoid wasp Metadontia amoena Say reported by Whitaker (1984a, b). Metadontia amoena is a specialist parasitoid of lycaenid pupae (Burks 1940). Figure 13 shows a hollow pupal exoskeleton from which a parasitoid (probably Metadontia amoena Say) had emerged.

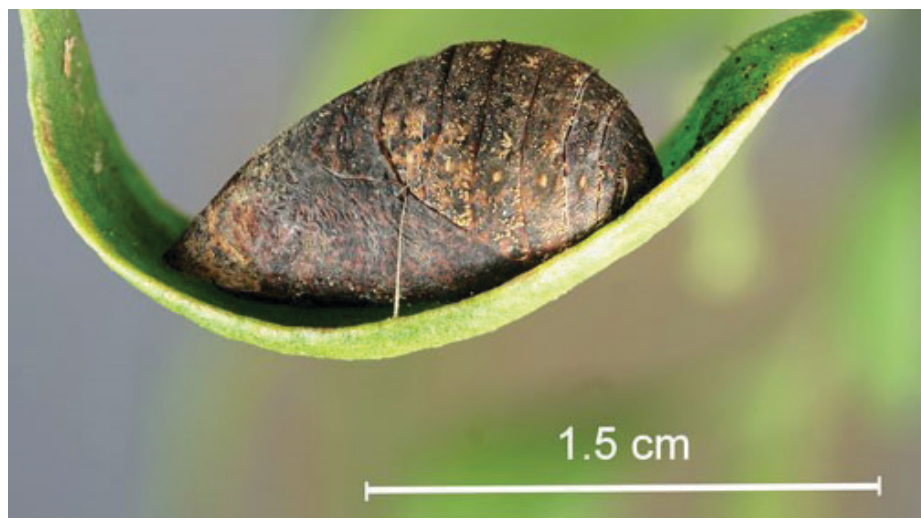

Figure 13. Great purple hairstreak, Atlides halesus (Cramer), empty exoskeleton of pupa that had been parasitized (probably by Metadontia amoena Say).

Credits: Donald W. Hall, UF/IFAS

I could find no records of predation on great purple hairstreaks in the literature, but larvae, pupae, and adults have colorations or behaviors that appear to have defensive functions against potential vertebrate predators.

\section{Defenses}

\section{Larvae}

Larvae are cryptic (camouflaged) on mistletoe.

\section{Pupae}

Pupae are cryptically colored and are usually found in crevices in bark, under loose bark, or under leaf litter at the bases of tree where they are usually hidden from sight (Opler and Krizek 1984). When touched they squeak (Downey and Allyn 1973), which may have a defensive function (Minno and Minno 1999).

\section{Adults}

False head: After landing, the butterfly turns around so its head is oriented downward and the tails are oriented upward (Winkler 1977). As with the other hairstreak butterflies, perching adults move their hind wings up and down (Sourakov 2017). The tails on the hind wings with their associated spots resemble a head. The movement of the tails is believed to attract a potential predator's attention to that part of the wings which then is torn away, allowing the butterfly to escape. Sourakov (2013) demonstrated that the false head of the red-banded hairstreak, Calycopis cecrops (Fabricius), allowed it to escape attack by the jumping spider, Phidippus pulcherrimus Keyserling. 
Smith et al. (1994) suggested that great purple hairstreak larvae may sequester toxins from their mistletoe hosts and that the bright coloring of adults may serve as a warning to potential predators. The adults rest with their wings together exposing the bright orange underside of the abdomen and the reddish-orange spots on the bases of the wings. Orange colors have been demonstrated to be particularly effective as deterrents to predators (Pegram and Rutowski 2014).

\section{Selected References}

Allen TJ. 1997. The Butterflies of West Virginia and Their Caterpillars. University of Pittsburgh Press. Pittsburgh, Pennsylvania. 388 pp.

Borror DJ. 1960. Dictionary of Word Roots and Combining Forms. Mayfield Publishing. Palo Alto, California. 134 pp.

Brown F. 1941. Some notes on four primary reference works for Lepidoptera. Annals of the Entomological Society of America 34(1): 127-138.

Burks BD. 1940. Revision of the chalcid-flies of the tribe Chalcidini in America north of Mexico. Proceedings of the United States National Museum 88(3082): 237-354.

Cech R, Tudor G. 2005. Butterflies of the East Coast: An Observer's Guide. Princeton University Press. Princeton, New Jersey. 345 pp.

Coder KD. 2008. American Mistletoe (Phoradendron serotinum var. serotinum) Infection in Trees. Tree Health Series. Warnell School of Forestry and Natural Resources. University of Georgia. Athens, Georgia. 36 pp.

Downey JC, Allyn AC. 1973. Butterfly ultrastructure. 1. Sound production and associated abdominal structures in pupae of Lycaenidae and Riodinidae. Bulletin of the Allyn Museum. No. 14. The Allyn Museum of Entomology. Sarasota, Florida. 47 pp.

eFloras.org. 2017. Phoradendron leucarpum (Rafinesque) Reveal \& M. C. Johnston. Flora of North America. Vol. 12, no. 6. (http://www.efloras.org/florataxon.aspx?flora $\mathrm{id}=1 \&$ taxon_id=242416983) (Accessed May 10, 2019)

Emmel TC. 1975. Genus ATLIDES Hübner. In: Howe WH. The Butterflies of North America. Doubleday. Garden City, New York. 633 pp.
Evens ZN, Stellpflug SJ. 2012. Holiday plants with toxic misconceptions. Western Journal of Emergency Medicine 8(6): 538-542.

Evans AV. 2008. Field Guide to Insects and Spiders of North America. Sterling Publishing. New York, New York. 497 pp.

Gerberg EJ, Arnett RH. 1989. Florida Butterflies. National Science Publications, Inc. Baltimore, Maryland.

Gledhill D. 1989. The Names of Plants. 2nd Ed. Cambridge University Press. New York, New York. 202 pp.

Hall AH, Spoerke DG, Rumack BH. 1986. Assessing mistletoe toxicity. Annals of Emergency Medicine 15: 1320-1323.

Haskin JR. 1933. Thecla halesus, its life cycle and habits. Entomological News 44:72-74.

Hutton K. 2010. A comparative study of the plants used for medicinal purposes by the Creek and Seminole Tribes. M.S. thesis. University of South Florida. Tampa, Florida. 150 pp. (https://scholarcommons.usf.edu/etd/1665/) (Accessed May $10,2019)$

Krenzelok EP, Jacobsen TD, Aronis J. 1997. American mistletoe exposures. American Journal of Emergency Medicine 15: 516-520.

Kuijt J. 1982. The Viscaceae in the southeastern United States. Journal of the Arnold Arboretum 63: 401-410.

Martins ARP, Duarte M, Robbin RK. 2018 (25 September). Hairstreak butterflies (Lepidoptera, Lycaenidae) and evolution of their male secondary sexual organs. Cladistics 1-25. https://doi.org/10.1111/cla.12355 (Accessed May 10, 2019)

Miller JY (ed). 1992. The Common Names of North American Butterflies. Smithsonian Institution Press. Washington, D.C. 177 pp.

Minno MC, Butler JF, Hall DW. 2005. Florida Butterfly Caterpillars and their Host Plants. University Press of Florida. Gainesville, Florida. 341 pp.

Minno MC, Minno M. 1999. Florida Butterfly Gardening. University Press of Florida. Gainesville, Florida. 210 pp.

Moerman DE. 2009. Native American Medicinal Plants: An Ethnobotanical Dictionary. Timber Press. Portland, Oregon. 799 pp. 
Moth Photographers Group. Undated. "Large Map and Chart" link. http://mothphotographersgroup.msstate.edu/ species.php?hodges=4270 (Accessed May 10, 2019)

Opler PA, Krizek GO. 1984. Butterflies East of the Great Plains. Johns Hopkins University Press. Baltimore, Maryland. $294 \mathrm{pp}$.

Pegram KV, Rutowski RL. 2014. Relative effectiveness of blue and orange warning colours in the contexts of innate avoidance, learning and generalization. Animal Behaviour 92: 1-8.

Plants Database. 2019. Natural Resources Conservation Service. United States Department of Agriculture. https:// plants.usda.gov/core/profile? symbol=PHLE14 (Accessed May 10, 2019)

Pyle RM. 1981. The Audubon Society Field Guide to North American Butterflies. Alfred E. Knopf. New York, New York. 916 pp.

Rosell S, Samuelsson G. 1966. Effect of mistletoe viscotoxin and phoratoxin on blood circulation. Toxicon 4(2): 107-110.

Samuelsson G, Ekblad M. 1967. Isolation and properties of phoratoxin, a toxic protein from Phoradendron serotinum (Loranthaceae). Acta Chemica Scandinavica 21: 849-956.

Scharpf RF, Hawksworth FG. 1974. Mistletoes on hardwoods in the United States. Forest Pest Leaflet 147. Forest Service, United States Department of Agriculture. 7 pp.

Scott JA. 1986. The Butterflies of North America. Stanford University Press. Stanford, CA. 583 pp.

Scudder SH. 1876. Synonymic list of the butterflies of North America, north of Mexico. Bulletin of the Buffalo Society of Natural Sciences 3: 98-129.

Smith DS, Miller LD, Miller JY. 1994. The butterflies of the West Indies and south Florida. Oxford University Press. New York, New York. 264 pp.

Sourakov A. 2013. Two heads are better than one: False head allows Calycopis cecrops (Lycaenidae) to escape predation by a jumping spider, Phidippus pulcherrimus (Salticidae). Journal of Natural History 47: 1047-1054.
Sourakov A. 2017. Great Purple Hairstreak Atlides halesus (Lycaenidae: Theclinae) feeds on goldenrod at UF Natural Area Teaching Laboratory (NATL). (https://www.youtube. com/watch?v=b_JEera6FKE) (Accessed August 13, 2019)

Spooner DM. 1983. The northern range of eastern mistletoe, Phoradendron serotinum (Viscaceae), and its status in Ohio. Bulletin of the Torrey Botanical Club 110(4): 489-493.

Whittaker PL. 1984a. Population biology of the great purple hairstreak, Atlides halesus, in Texas (Lycaenidae). Journal of the Lepidopterists' Society 38(3): 179-185.

Whittaker PL. 1984b. The Insect Fauna of Mistletoe (Phoradendron tomentosum, Loranthaceae) in Southern Texas. The Southwestern Naturalist 29(4): 435-444.

Winkler VT. 1977. Ein Zipfelfalter (Atlides halesus Cramer $1779^{*}$ ) mit Pseudokopf (Lepidoptera: Lycaenidae, Theclinae). Zoologischer Anzeiger 198(1-2): 31-35.

Wunderlin, RP, Hansen BF, Franck AR, Essig FB. 2019. Atlas of Florida Plants. Institute for Systematic Botany, University of South Florida, Tampa, Florida. http://florida. plantatlas.usf.edu (Accessed May 10, 2019)

York HH. 1909. The Anatomy and Some of the Biological Aspects of the "American Mistletoe" Phoradendron flavescens (Pursh) Nutt. Bulletin of the University of Texas Scientific Series No. 13, Number 120. Austin, Texas.

Zomlefer WB. 1994. Guide to Flowering Plant Families. University of North Carolina Press. Chapel Hill, North Carolina. 430 pp.

*Winkler's description date "1779" for Atlides halesus is erroneous. The correct date is "1777” (see Brown 1941). 